ISSN 0258-7122 (Print), 2408-8293 (Online)

Bangladesh J. Agril. Res. 44(3): 513-524, September 2019

\title{
EGG DEPOSITION AND WEIGHT LOSS OF SEEDS BY PULSE BEETLE, Callosobruchus chinensis L. ON DIFFERENT GENOTYPES OF PULSES
}

\author{
S. AHMED ${ }^{1}$, A. HAQUE ${ }^{2}$, H. MAHMUD ${ }^{3}$ \\ AND K. M. KHALEQUZZAMAN ${ }^{4}$
}

\begin{abstract}
Lentil Lens culinaris Medik., mungbean Vigna radiata L. R. Wilczek, chickpea Cicer arietinum L. and blackgram Vigna mungo L. Hepper of different genotypes were tested against pulse beetle, Callosobruchus chinensis L. in the laboratory of the Department of Entomology, Bangladesh Agricultural University (BAU), Mymensingh to evaluate the number of eggs deposition and percent weight loss of seeds. Maximum number of eggs (73.1) was oviposited on chickpea and minimum (19.5) was found on blackgram. The highest (19.9\%) weight loss in seed was noted in chickpea and the lowest $(7.6 \%)$ was recorded in blackgram. On the basis of weight loss of seed, blackgram and mungbean exhibited as tolerant genotype, lentil with moderately susceptible and chickpea as susceptible. Genotypes ML-22 of lentil, MC-21 of mungbean, Hyprosola of chickpea and MAK-1-79 of blackgram were found tolerant as compared to other tested genotypes considering the reduced number of egg deposition and lowest loss of seed weight. Evidently, the percent weight loss was marked as positive correlation with number of eggs deposition in all the genotypes and the regression line resulted in increasing the number of eggs laid with the increase in percent weight loss.
\end{abstract}

Keywords: Cicer arietinum L., Callosobruchus chinensis L., Egg deposition, Seed, Susceptible, Vigna mungo L. Hepper.

\section{Introduction}

Pulses are valuable crops and different varieties are grown in most parts of the world (Alemayehu and Getu, 2015). Pulses play a vital role in the diet of common people of Asian countries including Bangladesh. Pulses are excellent sources of proteins $(20-40 \%)$, carbohydrates $(50-60 \%)$ and are fairly good sources of thiamin, niacin, calcium and iron (Bhalla et al., 2008).

Bangladesh has fertile land in most of the area all over the country which provides productive cultivation of pulses as well as satisfies the demand for native people. Pulses are damaged by a number of insect pests both in field and

${ }^{1}$ Deputy Secretary, Ministry of Textile and Jute, Secretariat, Dhaka, ${ }^{2}$ Professor, Department of Entomology, Bangladesh Agricultural University (BAU), Mymensingh2202, ${ }^{3}$ Chief Instructor, Agriculture Training Institute, Ishwardi, Pabna, ${ }^{4}$ Principal Scientific Officer, Spices Research Centre, Bangladesh Agricultural Research Institute (BARI), Shibganj, Bogura, Bangladesh. 
storage. Amongst many insect pests viz., legume pod borer Maruca vitrata (Geyer), gram pod borer, Helicoverpa armigera (Hubner), aphids Aphis craccivora Koch, whitefly Bemisia tabaci Genn., tobacco caterpillar Spodoptera spp., leaf hopper Empoasca spp. and thrips Megaleurothrips distalis Karny and Caliothrips indicus Bag. caused extensive damage to grain legumes under field conditions while bruchids Callobruchus spp. damaged the grain in storage (Reddy, 2009). Pulse beetle, Callosobruchus chinensis L. (Bruchidae: Coleoptera) is also of significant importance as a major insect pest of stored chickpea (Rajasri and Rao, 2012). Higher egg laying of C. maculatus on some pulses (cowpea, pigeonpea, greengram, and blackgram) might be due to their larger seed size and smooth surface in comparison to other pulses (chickpea and pea) and maximum oviposition on smooth surfaced seeds while wrinkled surface was least preferred for oviposition (Satya Vir, 1980). Seed volume also showed direct relationship with oviposition preference by $C$. maculatus on various pulses (Sharma et al., 2016). Increase weevilisation was noticed with increase protein content in gram (Cicer arietinum) (Saxena and Saxena, 2011). Moreover, bruchids have the unusual habit of laying eggs on unsuitable surfaces under conditions of host deprivation as observed by Wang, 2004. Phenol and protein contents of seeds also resulted significant contribution in influencing the egg deposition behavior (Chakraborty and Mondal, 2016). Higher phenol content of different pulses also extended the developmental period of pulse beetle $(C$. chinensis) and showed inhibitory effect in the developmental process of pulse beetle (Patel, 2002).

One of the major constraints in production of pulses is the insect pests which inflict severe losses both in the field and storage (Bhalla et al., 2008). Among these, pulse beetle, Callosobruchus maculatus (Fabricius) [Coleoptera: Bruchidae] is the major pest that causes serious damage and is cosmopolitan (Bhalla et al., 2008). However $C$. chinensis is not only considered to be the most destructive insect but also causing severe damage to the extent of $93.33 \%$ in different pulse crops ((Parsai et al., 1989). The insect spends its entire immature life in individual legumes seeds, where they cause weight loss of seed, decrease germination potential and diminish the market price as well as nutritional value. The eggs of $C$. chinensis are laid on pulse seeds, and the larvae and pupae complete their development inside the grain. Seeds damaged by bruchids were not fit for consumption (Deshpande et al., 2011; Bae et al., 2014) or planting and also reduced their aesthetic value (Singh, 2011; Sarwar, 2015). C. chinensis L. is also known to be prolific and rapid in breeding and can quickly cause a serious quantitative reduction as well as diminish nutritive value of stored grains (Alemayehu and Getu, 2015).

Bangladesh Institute of Nuclear Agriculture (BINA) has Chosen some genotypes of chickpea, lentil, mungbean and black gram in order to develop new variety. It is very important to study the resistance of these genotypes against the pulse beetle. The present study was undertaken to assess the egg deposition and the 
weight loss of seeds by Callosobruchus chinensis L. on different genotypes of pulse grain.

\section{Materials and Method}

The study was conducted in the laboratory of the Department of Entomology, Bangladesh Agricultural University, Mymensingh, Bangladesh during June September, 1999. Effect of different pulse genotypes was tested to assess the egg deposition and weight loss on pulse seeds by $C$. chinensis. The present study was carried out at room temperature from 28 to $33{ }^{\circ} \mathrm{C}$ with relative humidity of 68 to $75 \%$.

\section{Collection of Test Materials}

Four species of pulses, lentil Lens culinaris Medik., munghean Vigna radiata L., chickpea Cicer arietinum L. and blackgram Vigna mungo L. with five genotypes of each pulse were selected for this study. The seeds of all the pulse genotypes were collected from the Department of Genetics, Bangladesh Institute of Nuclear Agriculture, Mymensingh.

\section{Stock culture of pulse beetle}

Pulse beetles were collected from the Department of Entomology, Bangladesh Agricultural University, Mymensingh. They were kept in a large glass jar $(12 \mathrm{~cm}$ $\times 18 \mathrm{~cm}$ ) with $100 \mathrm{~g}$ seeds of gram to oviposit. The adult pulse beetles were shifted after oviposition and seeds along with eggs were left for emerging as adult in the jar. The newly emerged adults were again allowed to oviposit on new seeds and the procedure was continued to maintain a steady stock culture.

\section{Oviposition test}

Ninety grams of seed from each genotype of pulses were separated into three equal parts (each $30 \mathrm{~g}$ ) and kept in three Petri dishes $(8.5 \mathrm{~cm} \times 1.5 \mathrm{~cm})$. Each dish was considered as a replicate and total number of Petri dish was 60 . Four pairs of newly emerged adult pulse beetles were released in each Petri dish and were allowed to lay eggs. Randomly, five gram seeds of each replicate were used. The insects were separated and the number of eggs laid on seeds was counted with the help of magnifying glass after five days. Then the Petri dishes along with infested seeds were covered with lid and kept on the table for weight loss assessment.

\section{Weight loss assessment}

Initial weight of healthy grain was taken before exposing to pulse beetle. After completion of the counting of damaged seeds of each replication, the weight of all seeds exposed to attack by the pulse beetle were taken from each genotype for 
assessing the weight loss of pulse seeds due to infestation. The percentage of weight loss was calculated using following formula:

Percent weight loss $=\frac{\text { Initial weight }- \text { Final weight }}{\text { Initial weight }} \times 100$

\section{Data analysis}

Data were analysed by using analysis of variance and the mean values were compared by Duncan's Multiple Range Test (DMRT). Before statistical analysis the percent values were transformed by angular transformation. Correlation and regression coefficients were also estimated between number of eggs laid and percent weight loss of different genotypes of pulse grain.

\section{Results}

\section{Effect of different pulses on egg deposition and weight loss of seed}

The numbers of eggs deposited by the females of $C$. chinensis on different pulses are presented in Table 1. Significant difference was found among different pulses with number of eggs $(\mathrm{P}<0.01)$ deposition. Maximum number of eggs (73.1) was laid on chickpea, while the minimum (19.5) was found on blackgram. The number of eggs laid on chickpea (73.1) was more than three times compared to that of blackgram (19.5). In case of weight loss of seed, percent seed weight loss differed significantly among the pulses $(\mathrm{P}<0.01)$. Significantly the highest seed weight loss $(19.9 \%)$ was recorded in chickpea, while the lowest $(7.6 \%)$ was observed in blackgram and this was statistically identical to that of mungbean (8.9\%). On the basis of seed weight loss, blackgram and mungbean were tolerant genotype, but lentil was moderately susceptible while chickpea was susceptible.

Table 1. Number of eggs laid and percent weight loss by $C$. chinensis on seeds of different pulses

\begin{tabular}{lcc}
\hline \multicolumn{1}{c|}{ Pulses } & Number of eggs $($ Mean \pm SE) & Mean weight loss $(\%)$ \\
\hline Lentil & $56.0 \pm 1.7 \mathrm{~b}$ & $13.4 \mathrm{~b}$ \\
\hline Mungbean & $59.5 \pm 2.4 \mathrm{~b}$ & $8.9 \mathrm{c}$ \\
\hline Chickpea & $73.1 \pm 0.9 \mathrm{a}$ & $19.9 \mathrm{a}$ \\
\hline Blackgram & $19.5 \pm 0.07 \mathrm{c}$ & $7.6 \mathrm{c}$ \\
\hline
\end{tabular}

* Means in a column followed by the same letter are not significantly different

\section{Effect of different genotypes of lentil on egg deposition and wt. loss of grain}

The number of eggs laid on different genotypes of lentil was presented in Table 2. The number of eggs laid differed significantly among the lentil genotypes $(\mathrm{P}<0.01)$. The highest $(96.33)$ number of eggs were laid on BARI Masur-4, while 
the lowest on ML-22 (44.33) which was statistically similar to that of ML-432 (46.33), ML-9 (47.66) and ML-478 (45.33). The percentage of seed weight loss varied significantly among the genotypes $(\mathrm{P}<0.05)$. The maximum $(17.2 \%)$ seed weight loss was found in BARI Masur-4 whereas the minimum in ML-22 (11.4\%) was recorded and it was statistically identical to that of ML-432 (12.2\%), ML-9 (12.6\%) and ML- 478(13.4\%). Consequently all the genotypes categorized as tolerant except BARI Masur-4.

Table 2. Number of eggs laid and percent weight loss by $C$. chinensis on seeds of different genotypes of lentil

\begin{tabular}{lcc}
\hline Genotypes & Number of eggs $($ Mean \pm SE) & Mean weight loss $(\%)$ \\
\hline ML- 432 & $46.33 \pm 2.18 \mathrm{~b}$ & $12.2 \mathrm{~b}$ \\
\hline BARI Masur-4 & $96.33 \pm 8.74 \mathrm{a}$ & $17.2 \mathrm{a}$ \\
\hline ML-22 & $44.33 \pm 1.76 \mathrm{~b}$ & $11.4 \mathrm{~b}$ \\
\hline ML-9 & $47.66 \pm 2.33 \mathrm{~b}$ & $12.6 \mathrm{~b}$ \\
\hline ML-478 & $45.33 \pm 1.45 \mathrm{~b}$ & $13.4 \mathrm{~b}$ \\
\hline
\end{tabular}

* Means in a column followed by the same letter are not significantly different

Relationship between number of eggs laid and percent weight loss by $C$. chinensis on seeds of different lentil genotypes were presented in Fig. 1. The regression equation of $y=0.0955 x+8.01$ and the straight line in the figure indicated that linear relationship between number of eggs laid and percent weight loss were observed to be strongly positive correlation $\left(\mathrm{r}=0.9527^{* *}\right)$.

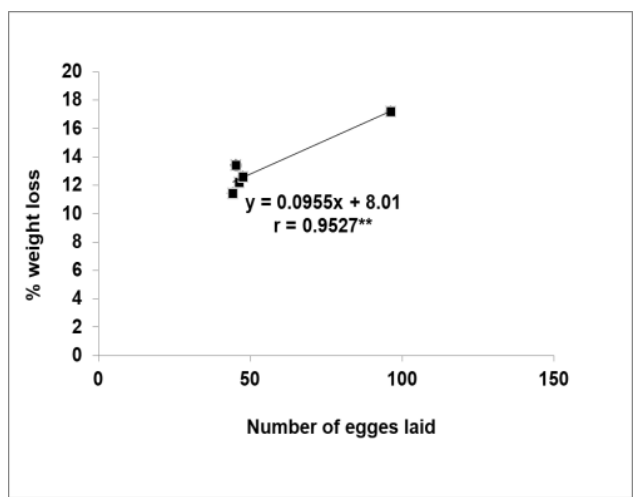

Fig. 1. Relationship between no. of eggs laid and \% weight loss by $C$. chinensis on seeds of lentil genotypes

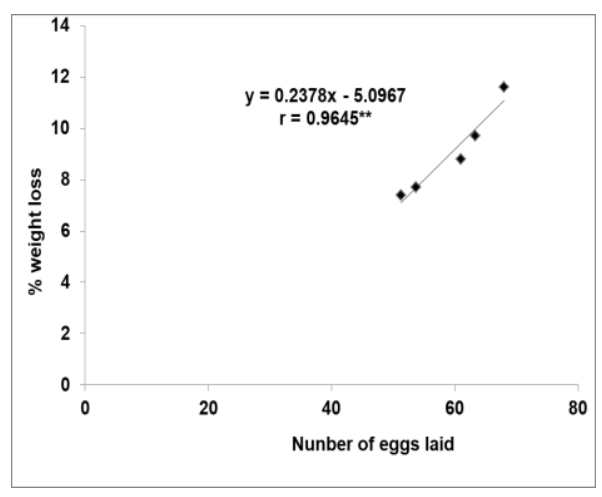

Fig. 2. Relationship between no. of eggs laid and \% weight loss by $C$. chinensis on seeds of mungbean genotypes

The regression line signified that increase of number of eggs laid with increase the percent weight loss of lentil genotypes.

\section{Effect of different mungbean genotypes on egg deposition and wt. loss of grain}

Significant differences among different genotypes of mungbean $(\mathrm{P}<0.05)$ with number of eggs laid by the beetles were shown in Table 3. The maximum 
number (68.0) of eggs was recorded on MC-26 which was statistically similar to that of Binamoog-5 (63.3) and MC-36 (61.0). The minimum number of eggs (51.3) was deposited in MC-21, which was statistically identical to Binamoog-2 (53.7). The difference among the genotypes in respect to seed weight loss was statistically significant $(\mathrm{P}<0.01)$. The highest loss $(11.6 \%)$ in weight was found with MC-26. The lowest loss in weight (7.4\%) was observed in MC-21 and this was statistically similar to that of Binamoog-2 (7.7\%). On the basis of this result, MC-21 and Binamoog-5 may be categorized as tolerant, on the other hand Binamoog-2 and MC-36 were moderately susceptible and MC-26 was susceptible.

Table 3. Number of eggs laid and percent weight loss by $C$. chinensis on seeds of different genotypes of mungbean

\begin{tabular}{lcc}
\hline Genotypes & Number of eggs $($ Mean \pm SE) & Mean weight loss $(\%)$ \\
\hline MC-26 & $68.0 \pm 2.1 \mathrm{a}$ & $11.6 \mathrm{a}$ \\
\hline Binamoog -2 & $53.7 \pm 1.8 \mathrm{bc}$ & $7.7 \mathrm{~cd}$ \\
\hline MC - 36 & $61.0 \pm 5.0 \mathrm{ab}$ & $8.8 \mathrm{bc}$ \\
\hline Binamoog-5 & $63.3 \pm 2.3 \mathrm{a}$ & $9.7 \mathrm{~b}$ \\
\hline MC-2I & $51.3 \pm 1.5 \mathrm{c}$ & $7.4 \mathrm{~d}$ \\
\hline
\end{tabular}

*Means in a column followed by the same letter (s) are not significantly different

Correlation and regression coefficients were estimated between number of eggs laid and percent weight loss by $C$. chinensis on seeds of mungbean genotypes presented in Fig. 2. The regression and correlation between number of eggs laid and percent weight loss were obtained with the equation of $y=0.2378 x-5.0967$ and correlation coefficient was $\mathrm{r}=0.9645^{* *}$. The relationship showed that the percent weight loss was strongly correlated (positive) with number of eggs laid in mungbean genotypes, while the regression line exhibited the increase of number of eggs laid, increased the percent weight loss.

Effect of different genotypes of chickpea on egg deposition and wt. loss of grain.

C. chinensis laid eggs on all tested genotypes of chickpea and their number differed significantly as shown in Table 4. Significantly the lowest number of eggs (55.7) on Hyprosola was recorded. The highest (84.3) number of eggs was laid on Barisola-3 which was statistically similar to that of P-34 (74.3), L-84 (76.7) and Binasola-5 (74.7). Significant difference among different genotypes of chickpea was found in respect of percent weight loss caused by the beetles ( $p<$ $0.05)$. Significantly the maximum weight loss $(23.6 \%)$ was observed in Binasola5 and categorized as susceptible, while the lowest (16.6\%) was considered as tolerant in Hyprosola and as moderately susceptible with P-34 (19.9\%), Barisola3 (19.7\%) and L-84 (20.0\%) genotypes (Table 4). 
Table 4. Number of eggs deposition and percent weight loss by $\mathrm{C}$. chinensis on seeds of different genotypes of chickpea

\begin{tabular}{lcc}
\hline Genotypes & Number of eggs $($ Mean \pm SE) & Mean weight loss $(\%)$ \\
\hline $\mathrm{P}-34$ & $74.3 \pm 4.91 \mathrm{a}$ & $19.9 \mathrm{ab}$ \\
\hline Hyprosola & $55.7 \pm 2.6 \mathrm{~b}$ & $16.6 \mathrm{~b}$ \\
\hline Barisola -3 & $84.3 \pm 3.28 \mathrm{a}$ & $19.7 \mathrm{ab}$ \\
\hline $\mathrm{L}-84$ & $76.7 \pm 2.33 \mathrm{a}$ & $20.0 \mathrm{ab}$ \\
\hline Binasola-5 & $74.7 \pm 5.78 \mathrm{a}$ & $23.6 \mathrm{a}$ \\
\hline
\end{tabular}

*Means in a column followed by the same letter are not significantly different

Number of eggs laid and percent weight loss of $C$. chinensis on seeds of chickpea genotypes were presented in Fig. 3. The regression equation $y=0.138 x+9.8639$ and the straight line in the Figure resulted positive correlation $(r=0.587 *)$ between number of eggs laid and percent weight loss through linear relationship. The regression line suggested that the increase in number of eggs laid was found to be increase the percent weight loss in chickpea genotypes.

\section{Effect of different blackgram genotypes on egg deposition and wt. loss of grains}

Egg depositions of $C$. chinensis on all the seeds of five blackgram genotypes were observed. Laying of eggs did not show any statistical differences among the genotypes. Maximum (22.0) number of eggs on M-25-54 was marked, while the lowest was recorded in MAK-1-79. Significantly the highest (9.0\%) weight loss in MAK-1 was considered as susceptible. The lowest weight loss $(6.1 \%)$ in MAK-1-79 was categorized as tolerant and this was statistically identical to that of M-25-54 (7.4\%) and M-25-58 (6.4\%) and was considered as moderately susceptible (Table 5).

Table 5. Number of eggs deposition and percent weight loss of grain by $C$. chinensis on different genotypes of blackgram

\begin{tabular}{lcc}
\hline Genotypes & Number of eggs (Mean \pm SE) & Mean weight loss $(\%)$ \\
\hline Binamash-1 & $19.0 \pm 1.2$ & $8.9 \mathrm{a}$ \\
\hline MAK-1-79 & $17.3 \pm 1.2$ & $6.1 \mathrm{~b}$ \\
\hline M-25-54 & $22.0 \pm 2.1$ & $7.4 \mathrm{ab}$ \\
\hline M-25-58 & $18.13 \pm 1.2$ & $6.4 \mathrm{~b}$ \\
\hline MAK-1 & $20.7 \pm 0.9$ & $9.0 \mathrm{a}$
\end{tabular}

*Means in a column followed by the same letter are not significantly different

Correlation and regression coefficients were evaluated between number of eggs laid and percent weight loss on seeds of blackgram genotypes (Fig. 4). Number of eggs laid and percent weight loss of grain was obtained in $\mathrm{y}=0.3732 \mathrm{x}+$ 
0.3109 and correlation coefficient was noted as $\mathrm{r}=0.5256^{*}$. The relationship showed that the percent weight loss was positive correlation with number of eggs laid on blackgram genotypes. The regression line indicated the number of eggs laid as increased the percent weight loss increased.

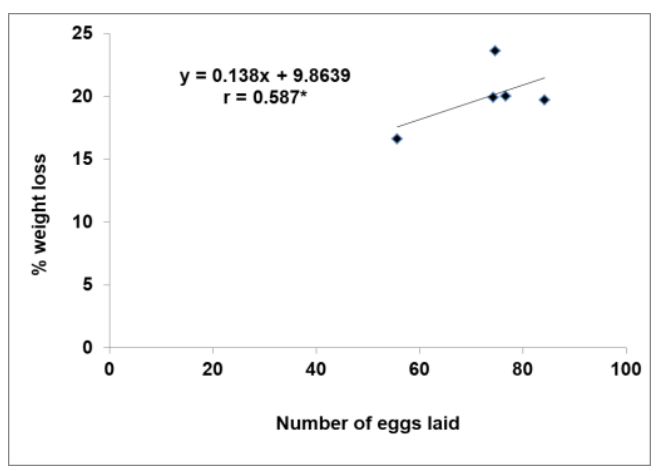

Fig. 3. Relationship between no. of eggs laid and \% weight loss by $C$. chinensis on seeds of chickpea genotypes

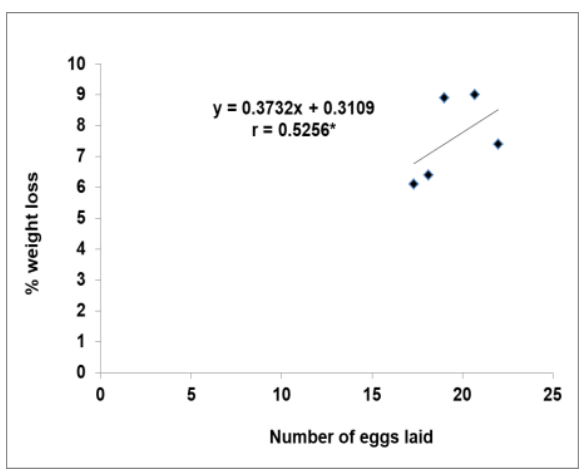

Fig. 4. Relationship between no. of eggs laid and \% weight loss by $C$. chinensis on seeds of blackgram genotypes

\section{Discussion}

Maximum eggs were deposited on chickpea and minimum eggs were laid on blackgram among the tested pulses. Cope and Fox (2003) reported that variation in seed size was important during oviposition periods. The seeds of chickpea were larger in size having larger surface area which favoured larger egg deposition. Chakraborty and Mondal (2016) also reported that pulse beetle laid maximum number of eggs in larger surface area of seed, and penetration and initial development was resulted with loss of grain weight. The results were also supported with the observation of Singh (1976) who reported that C. chinensis preferred oviposition on chickpea followed by mungbean, lentil, blackgram and bean in order of decreasing suitability. Bhaduria and Jakhmola (2006) reported that the ovipositional preference and survival of the pulse beetles on blackgram were less preferred. This was in conformity with the observation of Teotia and Singh (1968) who reported that wrinkled, depressed or rough seed coat of the host seed was relatively less preferred for oviposition and were unsuitable for development of insects. Kamble et al. (2016) reported that medium size seed with thin seed coat characteristics were found to be least preferred for oviposition as compared to bold seeded varieties, while the seeds of lentil and mungbean were smaller in size than blackgram but the egg deposition was higher on lentil and mungbean seeds.

The highest (19.9\%) weight loss in chickpea seed was recorded and this pulse was most susceptible, while the lowest (7.6\%) was observed in blackgram. The number of larvae of $C$. chinensis feed inside the seeds responsible for higher 
damage and weight loss. Bharathi et al. (2016) reported that $C$. chinensis was evaluated on eight different host-grains viz., greengram Vigna radiate L., blackgram Vigna mungo L., bengalgram Cicer arietinum L., redgram Cajanus cajan L., cowpea Vigna sinensis L., soybean Glycine max L., pea Pisum sativum L. and pillipesara Phaseolus trilobus L. and bengalgram exhibited significantly maximum percentage of weight loss of grains $(58.55 \%)$. These findings were also in accordance with the observation of Radha and Susheela, 2014 and Osman et al., 2015 who reported that the grain legumes affected by seed weight loss due to infestation. Demnati and Allache (2014) reported that chickpea seed weight loss was observed due to chickpea beetle infestation. These findings were supported by Aslam (2004). Similar findings were reported by Hossain et al. (2014) and found the highest seed infestation $(64.34 \%)$ and $(4.17 \%)$ weight loss in chickpea seeds. Besides this, chickpea was found more suitable and blackgram was less suitable for feeding by the pulse beetle larvae. Mungbean seeds were the medium sized with weight loss of $8.9 \%$, while lentil seeds were the smallest sized with $13.4 \%$ weight loss. However, it was evident from the literature that higher seed weight and thick seed coat prolonged developmental period of beetle (Chakraborty et al., 2004).

The pulse beetle laid eggs on the seed coat and the larvae fed inside the seed. The rate of oviposition varied significantly among the genotypes of respective pulse species. Minimum number of eggs was deposited on the genotype ML-22 of lentil, MC-21 of mungbean, Hyprosola of chickpea and MAK.-1-79 of blackgram. Lower moisture content of seeds, seed weight and seed coat thickness showed negative correlation with oviposition, adult emergence percentage and total developmental period, while phenol, OD phenol and protein content exhibited positive correlation with oviposition and developmental period as reported by Chakraborty and Mondal (2016).

Evidently, the percent weight loss was observed as positive correlation with number of eggs laid of all the genotypes and the regression line indicated the number of eggs laid was increased with increase in percent weight loss. Weight loss in seed was varied significantly among the pulse genotypes. Minimum seed weight loss was noted in ML-22 of lentil, MC-2I of mungbean, Hyprosola of chickpea and MAK-1-79 of blackgram among the pulses. The present findings in seed weight loss by pulse beetle were noticed that the twenty tested genotypes of four pulses were not found free from seed weight loss due to pulse beetle infestation. This variation of eggs deposition on greengram genotypes might be attributed to some physical (seed size, seed coat texture) and biochemical parameters. These results are concomitant with some previous works, where bruchid laid maximum number of eggs on susceptible genotypes than the resistant one (Shivanna et al., 2011; Badii et al., 2013). Sarwar (2012) also studied that resistant lentil harboured significantly lower number of eggs, inhibited adult progeny development and decreased grain weight loss which indicating resistance. 


\section{Conclusion}

Pulse beetle exhibited higher susceptibility on chickpea and showed the lowest susceptibility in blackgram measured by egg deposition and percent seed weight loss. Small seed size with thin seed coat and smooth seed surface of seed characteristics were found to be least preferred for oviposition as compared to bold seeded pulses. Physical and various chemical parameters may also showed significant contributions in influencing the egg deposition and seed weight loss.

\section{References}

Alemayehu, M. and E. Getu. 2015. Callosobruchus chinensis (L.) (Coleoptera: Bruchidae) Management on stored chickpea using botanicals in Amhara Region, Ethiopia. Amer J. Exp. Agril. 8(3): 167-177.

Aslam, M. 2004. Pest status of stored chickpea beetle, Callosobruchus chinensis Linnaeus on chickpea. J. Entomol. 1(1): 28-33.

Badii, K., S.K. Asante and E.N.K. Sowley. 2013. Varietal susceptibility of cowpea (Vigna Unguiculata L.) to the storage beetle, Callosobruchus maculates (F). (Coleoptera: Bruchidae). Intern. J. Sci. Technol. Res. 2(4): 82-89.

Bae Do.S., H.J. Kim, B.P. Mainali. 2014. Changes in nutritional composition of soybean seed caused by feeding of pentatomid (Hemiptera: Pentatomidae) and alydid bugs (Hemiptera: Alydidae). J. Econ. Entomol. 107:1055-1060.

Bhaduria, N.S. and S.S. Jakhmola. 2006. Effect of intensity of infestation caused by pulse beetle on extent of losses and seed germination in different pulses. Indian $J$. Entomol. 68: 92-94.

Bhalla, S., K. Gupta, B. Lal, M. L. Kapur and R.K. Khetarpal. 2008. Efficacy of various non-chemical methods against pulse beetle, Callosobruchus maculatus Fab. ENDURE International Conference on Diversifying crop protection, La GrandeMotte, France. P. 1-14.

Bharathi, T.D., P.V. Krishnayya and T. Madhumathi. 2016. Assessment of population and damage of pulse beetle, Callosobruchus chinensis L. on different pulse grains. Entomon. 41(3): 209-214

Chakraborty, S. and P. Mondal. 2016. Physico-chemical parameters of pulses affecting the bruchid (Callosobruchus chinensis linn.) infestation. Asian J. Sci. Technol. 7(3): 2554-2560.

Chakraborty, S.N., N. Chaudhuri and S.K. Senapati. 2004. Correlation between seed parameters and relative susceptibility of mungbean genotypes to Callosobruchus chinensis during storage. Ann. Plant Prot Sci. 12: 48-50.

Cope, P.M. and C.W. Fox. 2003. Oviposition decisions in the seed beetle, Callosobruchus maculatus F. (Coleoptera: Bruchidae): Effects of seed size on super parasitism. J. Stored Prod. Res. 39: 355 - 356.

Demnati, F. and F. Allache. 2014. Effect of Verbascum sinuatum(Scrophulariaceae) on oviposition of Callosobruchus maculates (Bruchidae). J. Crop Prot. 3(3): 327-334 
Deshpande, V.K., B. Makanur, S.K. Deshpande, S.P. Adiger and M. Salimath. 2011. Quantitative and qualitative losses caused by Callosobruchus maculatus in cowpea during seed storage. Plant Arch. 11: 723-731.

Hossain, M.A., M.A. Alim, K.S. Ahmed and M.A. Haque. 2014. Insecticidal potentials of plant oils against Callosobruchus chinensis (Coleoptera: Bruchidae) in stored chickpea. J. Entomol. 34(3): 47-56.

Kamble, S.M., A.S. Bagde and R.R. Patil. 2016. Oviposition preference of Pulse beetle on different cultivars of chickpea. J. Global Biosci. 5(6): 4197-4201

Osman, M.A.M., M.F. Mahmoud, and K.M. Mohamed. 2015. Susceptibility of certain pulse grains to Callosobruchus maculatus (F.) (Bruchidae: Coleoptera) and influence of temperature on its biological attributes. J. Applied Plant Prot. Suez Canal University. 3: 9-15.

Parsai, S.K., R.R. Rawat and R.K. Choudhary. 1989. Ovipositional behaviour and preference of Callosobruchus phaseoli (Gyllehal.): Its extent of damage in storage seeds of different varieties of field bean. Bull. Grain Technol. 27(2): 103-106.

Patel, V.K., 2002. Studies on characterization of genotypes and seed storability against pulse beetle (Callosobruchus chinensis) in horse gram. M.Sc. Thesis, UBKV, Pundibari, Cooch Behar, West Bengal.

Radha, R. and P. Susheela. 2014. Efficacy of plant extracts on the toxicity, ovipositional deterrence and damage assessment of the cowpea weevil, Callosobruchus maculates (Coleoptera: Bruchidae). J. Entomol. Zool. Stud. 2:16-20.

Rajasri, M. and P.S. Rao, 2012. Neem formulation and sugar seed protectant against pulse beetle, Callosobruchus chinensis for long term storage of Bengalgram. IJABPT 3: 323-328.

Reddy, A. 2009. Pulses Production technology: Status and way forward. Economic. Politic. Weekly 34 (52): 73-80.

Sarwar, M. 2012. Assessment of resistance to the attack of bean beetle Callosobruchus maculatus (Fabricius) in chickpea genotypes on the basis of various parameters during storage. Songklanakarin J. Sci. Tech. 34(3): 287-291.

Sarwar, M. 2015. Extermination of insect pests (Coleoptera: Bruchidae) and damage of stored pulses by different methods in market. American J. of Market. Res. 1: 99-105.

Satya, Vir. 1980. Oviposition response and development of Callosobruchus maculatus on different varieties of cowpea. Bull. Grain Tech. 18: 200-203.

Saxena, B. and R. Saxena, 2011. Nutritional changes in stored chickpea, Cicer arietinum in relation to bruchid damage. J. Stored Prod. Postharvest Res. 2: 110-112.

Sharma, R., R. Devi, A. Soni, U. Sharma, S. Yadav, R. Sharma and A. Kumar. 2016. Growth and developmental responses of Callosobruchus maculatus (F.) on various pulses. Legume Research. 39(5): 840-843.

Shivanna, B.K., B.N. Ramamurthy, N.B. Gangadhara, D.S. Gayathri, H. Mallikarjunaiah and N.R. Krishna. 2011. Varietal screening of cowpea against pulse beetles, Callosobruchus maculatus (fab.) and C. Analis (fab.) Inter. J. Sc. Nature. 2: 238 -40 
Singh, R. 2011. Evaluation of some plant products for their oviposition deterrent properties against the Callosobruchus maculatus (F.) on chickpea seeds. J. Agril. Technol. 7: 1363-1367.

Singh, Y. 1976. Studies on relative resistance of important pulses to Callosobruchus maculatus (Fabricius) and Callosobruchus chinensis (Linnaeus). Entomol. Newsl. 6(2): 18-19.

Teotia, T.P.S. and V.S. Singh. 1968. The effect of host species on the oviposition, fecundity and development of Callosobruchus chinensis L. (Bruchidae: Coleoptera). Rev Appl Ent. 56(3): 171.

Wang, M. and S. Horng, 2004. Egg dumping and life history strategy of Callosobruchus maculatus. Physiol Entomol. 29: 26-31. 